\title{
Distance Education and Corporate Training in Brazil: Regulations and Interrelationships
}

\author{
Stella C. S. Porto and Zane L. Berge \\ University of Maryland \\ USA
}

\begin{abstract}
Distance education in Brazil has evolved more slowly than distance education offerings in other developing countries. This is because all aspects of Brazil's publicly-funded educational system are excessively regulated, highly bureaucratic, and tightly centralized. Such highly centralized bureaucracy and strict control has resulted in tremendous hurdles that work to thwart the adoption, provision, and diffusion of distance education. This is not good news: Like many developing countries, Brazil is also characterized by wide gaps in wealth distribution, with 20 percent of its population functionally illiterate and living below the poverty line. Distance education, therefore, could be used to help train Brazil's citizens. Brazil's emerging status in the global economy, however, is generating enormous opportunities that are fueling demand for change. For example, in their quest to be competitive in the emerging global economy, Brazil's corporate sector has addressed this challenge by establishing corporate universities to train and educate their employees; much of this corporate training and education takes place online and at a distance. The established and emerging educational opportunities provided by Brazil's corporate sector, in turn, is fuelling the demand for the provision of distance education throughout Brazil. Indeed, most Brazilians are ready for distance education. Many Brazilian households own television sets and cellular telephones, and its expanding communication infrastructure has capacity to support distance and continuing education models. Moreover, this capacity is currently being used by Brazil's rapidly expanding corporate university sector. In spite of Brazil's emergence in the global marketplace and its private-sector educational success stories, Brazil's public educational institutions have not kept pace. This is due to Brazil's long-standing stringent regulation of its public education sector. Recent public initiatives, however, such as the Open University of Brazil, do hold promise in fueling the growth of distance education to meet the needs of its citizens, poor and rich alike. This paper analyzes the evolution of distance education in Brazil. It explores interrelationship between the nation's corporate and publicly-funded highereducation sectors, and the influences Brazil's highly regulated distance education practices has on the corporate environment. The paper concludes with a broad-brushed overview of 'success stories' of Brazil's corporate universities.
\end{abstract}

Keywords: Brazil; corporate universities; higher education; distance education 


\section{Introduction}

Geographically, Brazil is the largest country in South America and the fifth largest country in the world (National Geographic, 2007). Brazil's current population is approximately 190 million; 68 percent are between the ages of 15 to 64 years (The World Fact Book, 2007). Unlike many of its Spanish speaking neighbors in South America, Brazil's native language is Portuguese. Just over 80 percent of Brazil's population is functionally literate (i.e., defined as basic reading and writing skills for those 15 years or older).

Brazil's history as an independent state is divided into different periods, based on the kind of government, starting with the Old Republic (or First Republic), which lasted between 1889 and 1930. The period is marked by a constitutional democracy, where presidents from the two major agricultural South Eastern states of Minas Gerais and São Paulo would alternate in power. It was time of major economic dependence on mono-agriculture cycles, such as rubber and coffee, where the "colonel" - that is the landowner - was the main prominent and influential figure. The Revolution of 1930 brought into power Getulio Vargas, who became a dictator for almost 15 years. Between 1945 and 1961, Brazil had a sequence of democratically elected presidents. In 1964, a military movement, supported internally by national conservative forces and externally by the United States, resulted in a coup over the current president - Joao Goulart, who was seen as bringing socialist reforms to the country. The fear was that Brazil would become a new Cuba in South America. Brazil entered a long phase of military dictatorship with no free press or free speech. Prosecution, imprisonment, exile, and torture of opposition activists and leaders became commonplace. After decades of military rule, the late 1980s saw Brazil emerge as a democratic state. The 1980s, however, were bleak times for many Brazilians. The South American nation was in the midst of transitioning from military rule and thus lacked economic stability. The 1990s brought nearly a decade of economic inflation, resulting in more economic hardship for Brazilians. The new Millennium, however, has brought greater economic stability to Brazil, as witnessed by its ever increasing participation in the global marketplace. Brazil's economic transformation, however, has happened without any concomitant increases in real wages or employment standards for most Brazilians. In spite of all the challenges currently facing Brazil, however, its economy currently surpasses those of all other South American nations. Indeed, Brazil boasts of well-developed mining, manufacturing, and service sectors, all which help to fuel its economic growth and underpin its economic stability (The World Fact Book, 2007). Although doing business in Brazil is more stable these days, and the nation's economic future looks more promising, many Brazilians still face severe social-economic challenges, such as high domestic and foreign debt, and high unemployment rates of approximately 10 percent. Moreover, over 20 percent of Brazilians currently live under the poverty line. In spite of Brazil's economic emergence in the global economy and related economic growth, there remain wide gaps in income distribution; indeed, Brazil currently has a Gini index of almost $60^{\mathrm{i}}$ (The World Fact Book, 2007).

Although many Brazilian households, in certain areas, lack modern conveniences, more than 90 percent of Brazilian households do own a television (approx. 50 million televisions), and new high definition television systems are being planned for the near future. The number of mobile telephones outstrips that of televisions by nearly 100 percent. In 2005 there were just over 25 million Internet users in Brazil; by 2006, the number of Internet users in Brazil surpassed 6 million (The World Fact Book, 2007). In spite of Brazil's rapid uptake of communication technologies, wide divisions persist between the rich and poor. Today, one of the greatest challenges facing Brazil is that a significant portion of its citizens are illiterate and live below the poverty line. In spite of this apparent "digital divide,” Litto (2002a) predicted that because 
Brazilians are embracing technology, they are becoming "rather impatient with printed materials" ( 2). In other words, Brazilians are culturally open to technology and the change it brings with it. In terms of culture and infrastructure capacity, most Brazilians are generally well positioned to embrace and benefit from continuing education models, including distance education.

This paper analyzes the evolution of distance education in Brazil by focusing on corporate vis-àvis its public higher education sectors, and the impact Brazil's current regulatory environment has on these public and private sector educational initiatives. This paper provides examples of distance education in Brazil, and draws parallels from both the public and private educational sectors to illustrate its argument.

\section{Education in Brazil}

A quick overview of Brazil's historical legacy reveals several factors that influence its current approach to education. In the early 1800s, Brazil's first higher education institutions were created. It was during this time that a domestic press emerged and publications were allowed in the Portuguese colony. Shortly thereafter, Brazil gained political independence from Portugal in 1822. But in spite of these significant inroads towards independence, an extremely powerful political and economic elite still maintained control of Brazil, achieved primarily through their political dominance in Brazil's governing and administrative bodies. Unfortunately, Brazil's ruling elite did little to ameliorate the living conditions of poorer citizens. For example, the period in Brazilian history called the "First Republic" (1890-1930), only 25 percent of the population was deemed literate (Anderson, 1991). According to Anderson (1991) and Litto (2006), this historical legacy of elitism resonates to this very day, and is responsible for the cultural reification of Brazil's longstanding relationship to power, policy, and control. Brazil can currently be characterized by "centralized dominance" wherein any "organized activity or spontaneous solidarity" (Litto, 2006, p. 4) tends to be either tolerated and/ or silenced. Moreover, this ongoing dynamic of cultural reification and essentially unquestioned compliance to hegemony of Brazil's ruling elite tends to reinforce and legitimize the nation's highly centralized and highly plutocratic power and control structures. Corruption and nepotism are not only natural consequences of culturally surrendering to Brazil's ruling elite; such behavior tends to be viewed as commonplace and perhaps even normal.

It is the authors' observations that such characteristics remain embedded in Brazil's current government. Moreover, this level of acceptance of the power structures of its ruling class strongly influence all Brazilian institutions on all levels of governance, from federal to local administration. Brazilians tend to be mostly inured to such intrinsic corruption, because it has been the way that life is in Brazil. Citizens tend to believe that anyone coming into power will repeat self-serving behaviors of their predecessors, independent of whatever party or political background they represent. Brazilian politics is now the brunt of many jokes, and many citizens are starting to express disillusionment. The summative effect is that many Brazilians now lack confidence and trust in their government.

Culturally, Brazil embraces its strong tradition of "patrimonialism” (Litto, 2006), meaning most Brazilians tend to be comfortable following the dictates of the status quo - following the laws set forth by Brazil's centralized and highly patriarchal powerbrokers, without questioning them too deeply. This level of broad-based cultural acceptance reificates and reinforces political favoritism and nepotism within Brazilian bureaucratic organizations, including its public higher educational institutions. As such, Brazil remains subject to over-regulation and bureaucratic red-tape that formally and informally legitimizes current power structures, and thus presents formal and 
formidable obstacles to 'getting things done' in the new global economy that demands a welltrained workforce.

Brazil's Ministry of Education, the nation's highest regulatory authority overseeing and administering the country's educational system, has a long history of governing its educational system by means of legislative decrees, most of which are not formally debated in parliament. More often than not, Brazilian society simply accepts the conduct of its politicians and bureaucrats without significant questioning or challenges. Brazilian's culture of 'shouldershrugging acceptance' has an arguably direct and negative impact on innovation, experimentation, and creativity. Indeed, the subtle shift from government to governance observed in other developing countries in recent years has yet to take shape in Brazil. As a result, in terms of deploying distance education methods to meet its ever escalating educational needs, Brazil's public education sector has not kept pace with advances experienced in similarly developing countries.

\section{Brazilian Distance Education}

According to recent studies of underdeveloped countries (Romiszowski, 2005), the creation of dedicated distance education higher education institutions have resulted in an increase in service capacity, sometimes by as much as 20 percent. Some project that the adoption of distance education in dual-mode higher education institutions in these countries will eventually serve more than 50 percent of the students enrolled in higher education. Unfortunately, Brazil is not yet on this list of successful national case studies.

When examining and pondering the reasons why distance education has not been readily adopted by Brazil's higher education system to expand access, Litto (2002a) opined that such dismissal relates directly to Brazil's highly centralized and regulated education system. Litto also cites the "widespread lack of credibility of [distance education] approaches both inside and outside academic communities” (p. 1) as another factor impeding the deployment and use of distance education throughout Brazil.

Indeed, Brazil can be categorized as belonging to the old European school in terms of its highly centralized approach to administering education (Litto, 2006). Unlike Europe, which has relaxed its rules, Latin America as a whole, and Brazil in particular, has not evolved, and over time its educational system has become even more inflexible, and its rules non-negotiable. For example, legislative planning time is typically short, changes are frequent, and this dynamic results in instability, lack of trust, and an increasing misuse of bureaucratic power (Armengol, 2002). Moreover, according to Litto (2006), Brazil, an enormous nation in both size and population, presents an "uneven history of growth and development in the use of learning at a distance" (p. 1). The historical factors leading to Brazil's increasingly bureaucratic regulation over distance education have also been identified by Romiszowski (2005). From 1998 through 2001, diplomas from foreign universities earned at a distance education were not officially recognized in Brazil (Litto, 2006). Additionally, all post-secondary diplomas and degrees were only allowed a ceiling of 20 percent of distance learning time. Brazilian distance education courses to this day require students to interact with their institutions face-to-face for examinations, final project presentations, and dissertations. In addition to these formally legislated barriers, are fears that academic dishonesty will prevail and that Web-based learning lacks any real pedagogical ability to educate effectively. Despite these perceived obstacles, there are currently three million learners enrolled in courses offered at a distance throughout Brazil. Of these three million distance students, 1.5 million are registered in corporate initiatives. Of these private sector educational 
offerings, Telecurso 2000, currently serves over .5 million students and delivers "primary and secondary school education to adults through open-circuit television and printed material" (Litto, 2006, p. 12). The remainder of Brazilians studying at a distance tends to be enrolled in a variety of authorized extension courses, university programs, vocational education (Bof, 2004) and radiobased courses (Wikipedia, 2008).

In December 2005, Brazil's president signed new laws into effect, thus "establishing the policies and norms of distance education in the country" (Litto, 2006, p.13). These laws (MEC, 2005) legislate that for basic education (i.e., primary and secondary levels) Brazil's accredited institutions are only legally allowed to offer distance education under two extenuating circumstances: learning complementation and emergency situations. In cases where distance education courses are designed to deliver basic level adult education, current law deems that it is under the authority of Brazil's state- and city-level jurisdictions to administer these offerings. In higher education (including undergraduate and professional education), institutions must adhere to accreditation processes as defined by Brazil's Ministry of Education, whether such programs are delivered at a distance or in traditional face-to-face modalities. All institutions must be accredited to deliver graduate-degree programs of study. In case of the 'lato sensu' graduate programs - that is graduate programs without dissertations - all institutions must include face-toface components, such as sitting for exams and defending final projects. Foreign degrees are only deemed transferable (i.e., recognized and registered by Brazilian universities) if they are accredited programs that cover the exact same content area. Legislation dating 2001, established that foreign institutions offering 'stricto sensu' graduate programs (i.e., programs with dissertations), directly or through partnership with Brazilian institutions, must immediately stop enrolling students. Arguably, this law illustrates the growing rigidity of Brazil's educational system, and attests to growing centralized decision-making taking place in Brazil's education sector. It is the authors' opinion that such legislation can potentially result in erecting roadblocks and bottlenecks the accreditation process.

In 2005, the creation of the Universidade Aberta do Brasil (Open University of Brazil - UAB) a consortium of several state institutions - was put into service to meet the growing demands of Brazilians seeking to complete their studies using a hybrid model of distance education and supported through a network of local learning centers. This project was a creation of the Ministry of Education, together with several of the major Government companies and Federal Universities in an attempt to democratize access to higher-education. UAB is not a new institution, but a system created to coordinate the efforts of different educational entities, at federal, state, and municipal levels, in the offering of higher-education in different modalities of distance education. One of the major activities within this project is the creation of local centers in areas where the access to higher-education is scarce. The project prioritizes the qualification of teachers working at the elementary level who have not yet obtained an undergraduate degree. 
Figure 1. Screenshot of Universidade Aberta do Brasil homepage

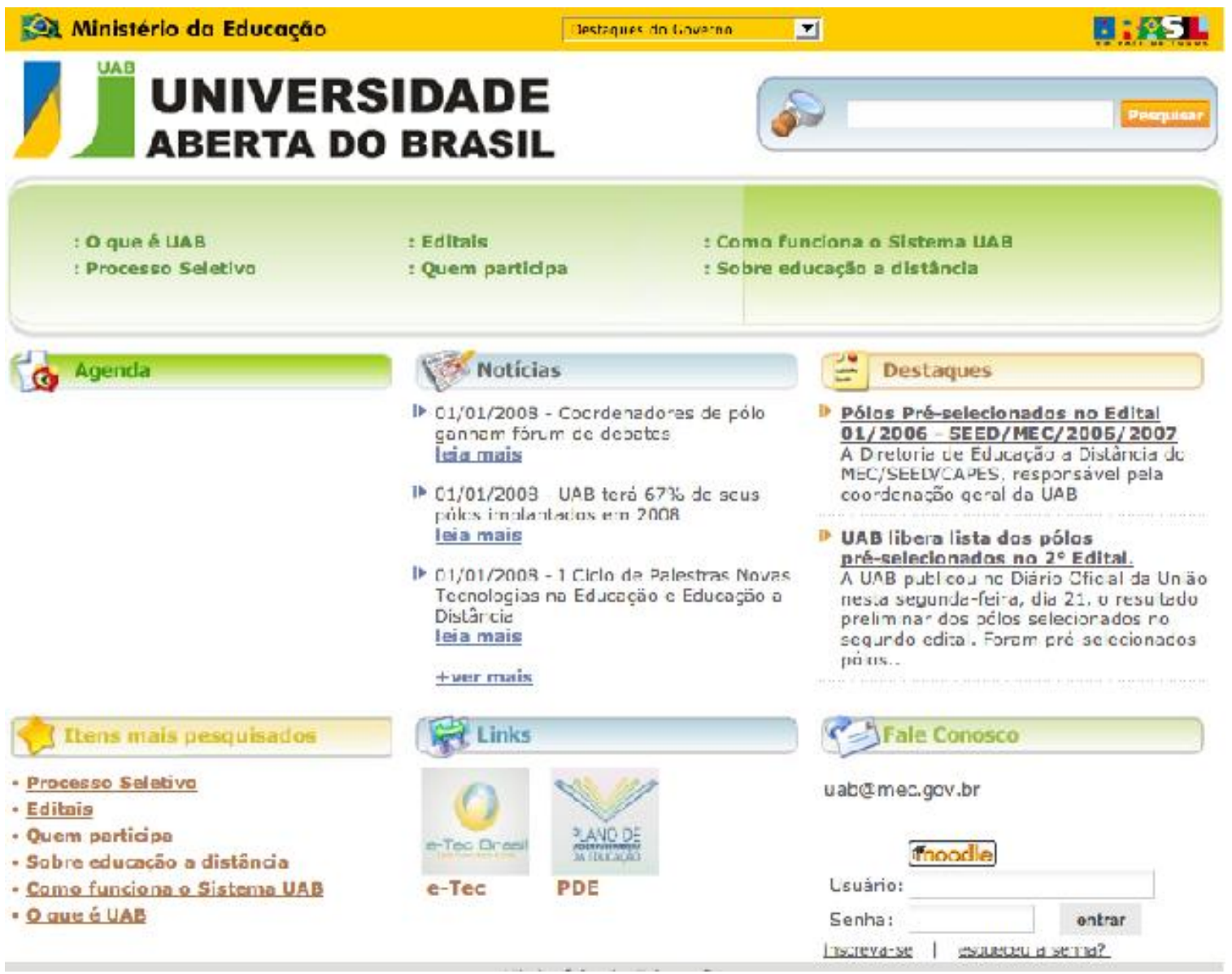

This initiative is a response to 2005 legislation, which required teachers, including those teaching at the elementary school level, to be qualified through an undergraduate degree. Since the inception of UAB, hundreds of these local centers have been created throughout the country. The participating institutions (all state run) will be able to offer courses through these centers to students who would not be able to engage in the higher-education system otherwise. The programs offered through UAB are also offered to those who have completed their secondary degree and have been approved previously in the selective entrance process of any of the highereducation institutions. It is too early to assess the success of this effort, however. Clearly, much will depend on the administrative and cooperative efforts of federal institutions of higher education and state- and municipal-level efforts, the latter of which must provide the local study centers and the front-line tutors who interact with students face-to-face, via phone, and via the Internet. In 2007, a similar initiative started at the professional education level. The Ministry of Education inaugurated the eTec Brasil - Open Technical School System of Brazil. The focus is the development of technical professional education using distance education, again with the goal of democratization of access. The interior of the country and the outskirts of Brazil's greater metropolitan areas are the target areas for supporting centers, which will be mainly located in municipal elementary school facilities to be adapted for these new functions. The model of distance education is similar to the one considered within UAB - that is print and other media materials developed specifically for these programs, which can be sent to students. Students will also interact with tutors face-to-face in the local centers. Face-to-face time, however, is again a requirement for assessment and major lab activities (Ministério da Educação, 2007). 
In spite of these recent hybrid initiatives, distance education in Brazil is still dominated by the use of print materials (Takahashi, 2006). Although the use of online education and CD-ROMs are ranked just after print materials in terms of production, distribution, and use, Brazil's higher educational institutions offering hybrid education still rely on a predominance of print-based learning materials for its distance components. This reality shows that Brazil's distance educational model still remains outdated, which can be viewed as inimical to student success, especially in light of the pervasive use and ownership of computers throughout Brazil. Indeed, the current hybrid model of distance education delivery remains more focused on traditional forms of course development delivered primarily through print based materials, which are then augmented by traditional face-to-face tutoring at local study centers and/ or via other technologies, such as television and online interaction with tutors. Because Web-based student-to-student and studentto-teacher interaction is not at the core of the pedagogy for distance education, the overall progress and effectiveness of distance education throughout Brazil lags far behind inroads being made in other developed and developing countries that are striving to embrace more informed models of distance education. Indeed, one will not find group activities or group assignments as part of distance education offerings in Brazil. Moreover, traditional programs tend to overwhelm its distance education components, and thus the pedagogies more relevant to face-to-face instruction and negate the power and effectiveness of its distance education components. Distance education should, ideally, be premised on pedagogical models that best underpin that delivery and learning method.

Given the legislative restrictions currently imposed on Brazil's public higher-education sector, Litto (2001; 2002b) determined that hybridization, that is the combination of face-to-face and distance delivery modalities, is nonetheless currently the best method to tap into distance education's potentialities. He also notes, however, that exceptions do exist for extension courses and non-degree programs, which can be wholly delivered at a distance. Litto (2002b) also observed that private-sector corporate universities, which currently operate apart from governmental controls, are increasingly expanding their educational offerings across Brazil to meet their corporate learning objectives. Clearly, the success of the corporate learning initiatives could well fuel demand for changes to start taking place in education across Brazil. Without access or use of technology-mediated communication in the form of Internet and Web-based learning, it remains questionable whether or not Brazilians will truly be prepared for the modern version of e-learning, whether it is currently offered from private-sector corporate universities, or from public education institutions someday down the road.

Two additional factors are blocking the adoption of distance education in Brazil: 1) there is currently no dedicated DE higher-education institution in Brazil, and 2) most of Brazil's public tertiary-level education is free, and thus funding for such e-learning initiatives come from public sources. Moreover, because Brazil has no established - let alone emerging - academic tradition in e-learning pedagogy and delivery, it is difficult to find homegrown experts to establish and manage distance education on a larger scale. Indeed, experts in charge of distance education in Brazil tend to be "academics with only a theoretical knowledge of distance education. . ." with "their practical experience is firmly rooted in the conventional face-to-face practices of the existing higher education institutions" (Romiszowski, 2005, p. 6). Another consideration is that Brazil's higher educational system lacks a market-driven focus. "Customer service" is simply not on the radar screens of most Brazilian public higher educational institutions, primarily because they are already being flooded with applicants. In most cases, only the best and brightest Brazilians are able to enter and benefit from their public higher education system. Moreover, the success of any given applicant is very much determined by the high school they attended prior to entering Brazil's higher education system. And given that Brazil's secondary school system is dominated by private-sector for-profit educational providers, few if any students from Brazil's 
under funded public school system will likely qualify for entry to higher education. While a good education is clearly important, many students from underprivileged backgrounds and socioeconomic situations can be successful learners. This illustrates that Brazil's higher education system does not cater to, nor does it support, students from the lower rungs of its socio-economic ladder. Moreover, because funding for Brazil's public higher educational institutions is not reliant on socio-economic factors, the handful of poor and disadvantaged students who do get admitted tend not to complain primarily because they are simply happy to have been accepted to receive free education in the first place.

\section{DE Initiatives in Brazil's Corporate Universities}

There has been significant growth in the number of corporate universities in Brazil in recent years. In the late 1990s, there were fewer than 20 corporate universities operating in Brazil; by 2003, however, that number expanded to 150 (Posseti, 2005). Many large private sector corporations such as Ambev (beverages), Accor (hotels), and Santander Banespa (banking) are investing in the development of continuous educational offerings for their staff and executives. In many cases, third party organizations are called upon to offer customized and off-the-shelf corporate training programs. This is the case of Ibmec (telecommunication) a corporate university operating out of São Paulo. From 2004 to 2005, Ibmec saw demand for its distance education offerings skyrocket by 40 percent, followed by a 30 percent increase for 2006 . One of the main characteristics of these corporate universities is that they can offer customized learning solutions to meet their customers' various educational needs and contexts. For example, the most commonly searched topics are: entrepreneurship, innovation, and creativity - all search terms that are illustrative of Brazilians' growing interest in doing business.

Litto (2002a) found many commonalities among Brazil's corporate universities. First, they are mainly seen as 'umbrellas' under which each company builds and organizes their corporate educational design and delivery systems. Their primary focus tends to be on continuing education with the aim of continually upgrading their employees' skills and knowledge to better serve their clients, suppliers, and the community they serve. The goal of their distance delivery curriculum tends to be related to basic or advanced use of technology; business competencies; corporate culture and values; general culture; and basic primary and secondary education. Other corporations have partnered with these private-sector academic institutions for external assessment purposes, and established programs that allow 'certification.' In most cases, Brazil's corporate universities operate under the direction of the company's human resources division, which in turn, reports to the chief executive officer. Corporate universities, which have historically relied on face-to-face modes of instruction, have, since the mid 1990s, moved to embrace distance mode of delivery. Today, many are using Web-based e-learning and virtual environments. As expected, these company's corporate universities had to bear high initial investment costs in the design and delivery of e-learning, but such investments were subsequently offset with gains in employee productivity and overall performance. In some cases, corporate training and educational initiatives has been so successful that these corporate universities, sensing new market opportunities and growing demand, have created their own 'educational brand' and have moved to offer their services to outside companies.

There is no consensus among corporate universities, however, on the buy-or-build issue. Some corporate universities have opted to produce their own materials independently, while others have outsourced their educational initiatives. Moreover, in Brazil's highly centralized and bureaucratized public educational system, certification still remains a thorny issue that has yet to be resolved. 
Figure 2. Screenshot of Ambev Brazil main webpage

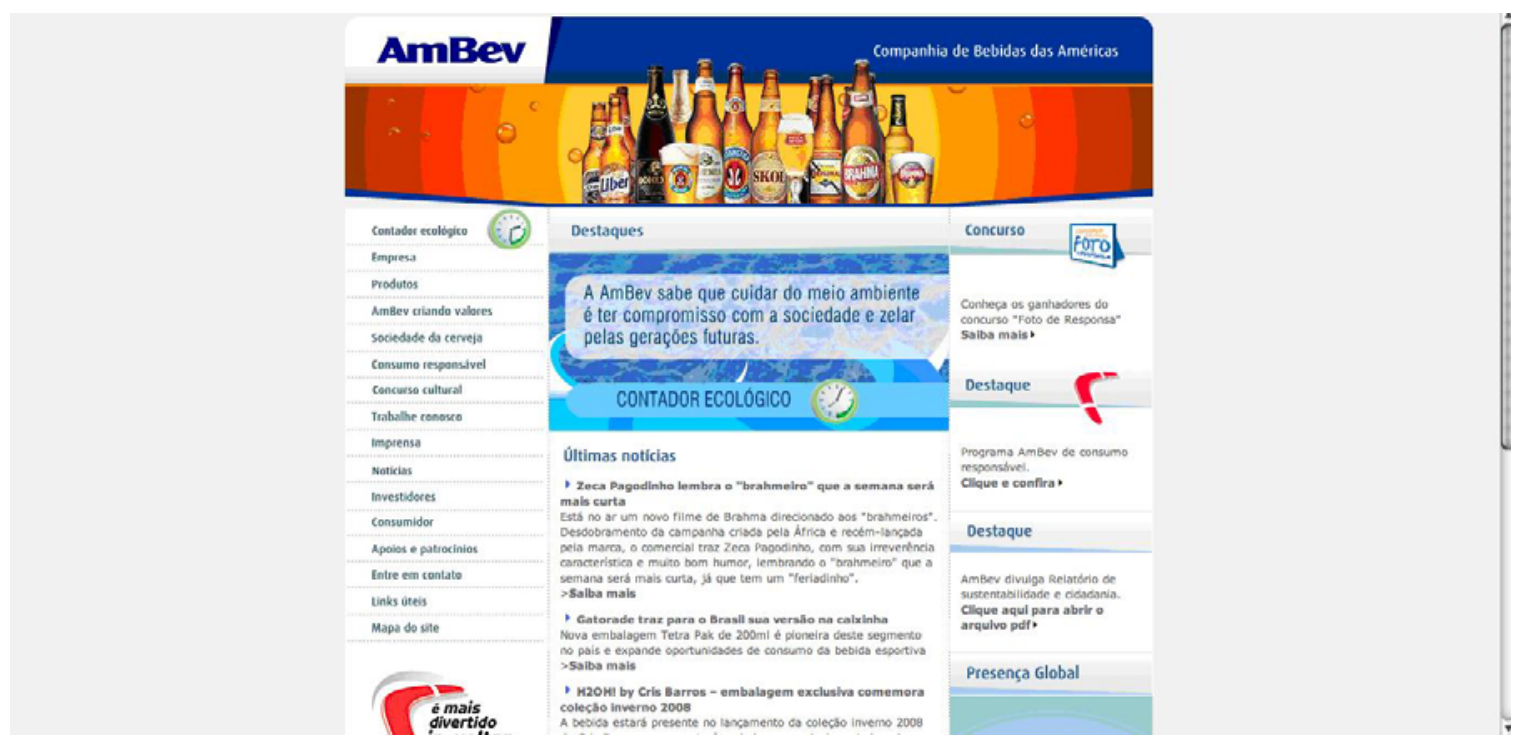

Ambev beverage's sector (AmBev, 2008) is one of the corporate pioneers in the genesis and growth of Brazil's corporate university system. In 1995, the company created the Brahma University, which was later changed to Ambev University (UA) (Posseti, 2005). Besides offering traditional face-to-face courses, UA also provides Ambev TV. Ambev TV employs satellite television and as such, its televised course offerings are broadcast nationwide simultaneously. Interestingly, television has been one of the major success stories in Brazilian distance education, underscoring the reality that Brazil's delivery capacity does, in fact, influence its corporate sector selection in terms of technology and media used for training and educational purposes.

Figure 3. Screenshot of Accor Brazil main webpage

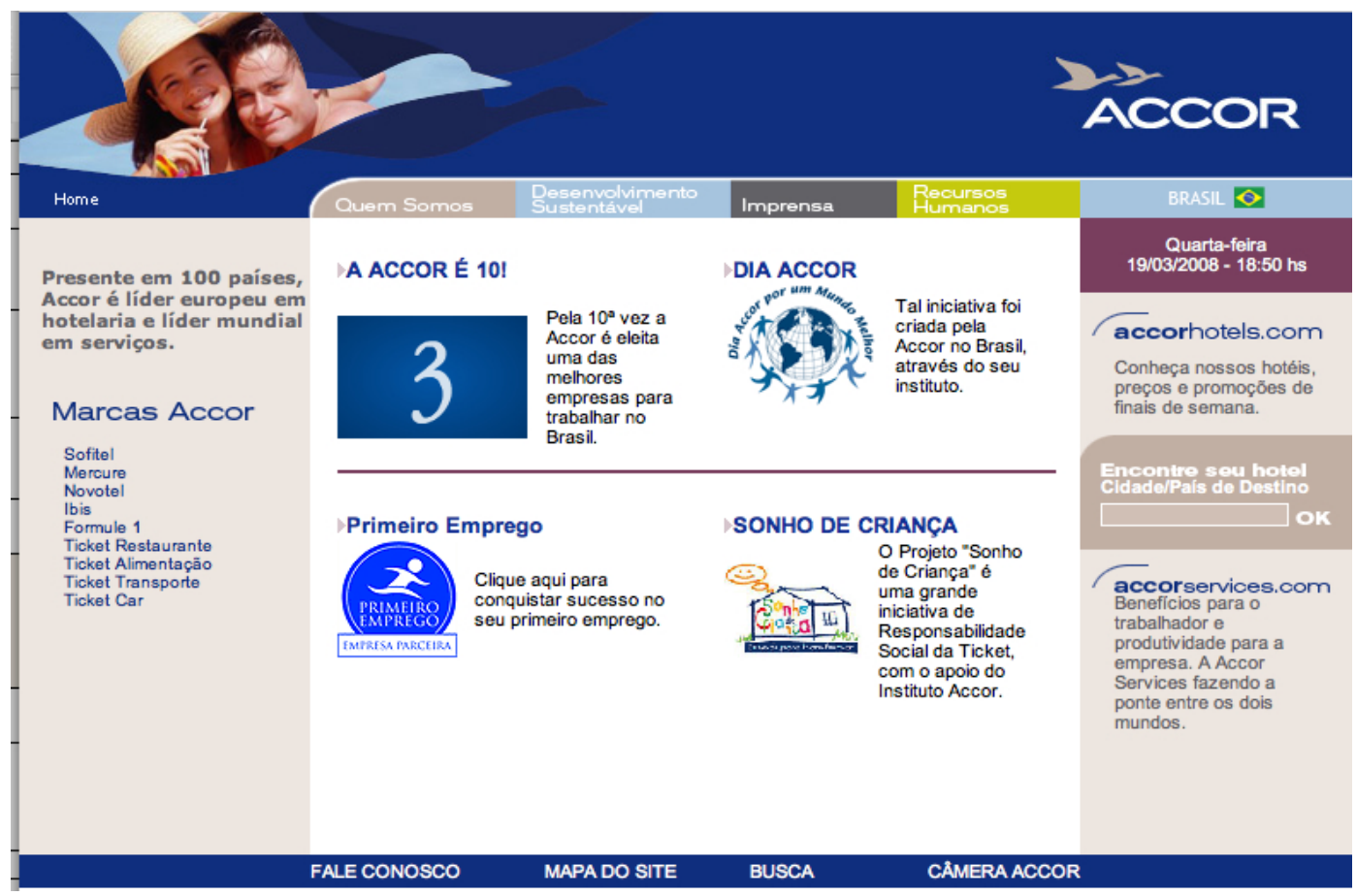


The Accor Group operates hotels and related services (Accor, 2008) and is headquartered in France. The Accor Group launched Brazil's first private-sector corporate university. Initially, the Accor Academy was established in Campinas, a neighboring city near São Paulo. The first course offered by Accor Academy was in the business subject area of 'leadership,' a course that is still offered to this day. A training unit still exists inside the company that provides training necessary for specific jobs and positions within the Accor Group. In sum, the Accor Academy is investing in its employees by providing them with the education they need to be prepared for changes happening in the global economy. Accor Academy's goal is to provide that company with a competitive edge pure and simple, and its employees benefit by becoming more rounded and better informed professionals.

Figure 4. Screenshot of Accor Academie Latin America webpage

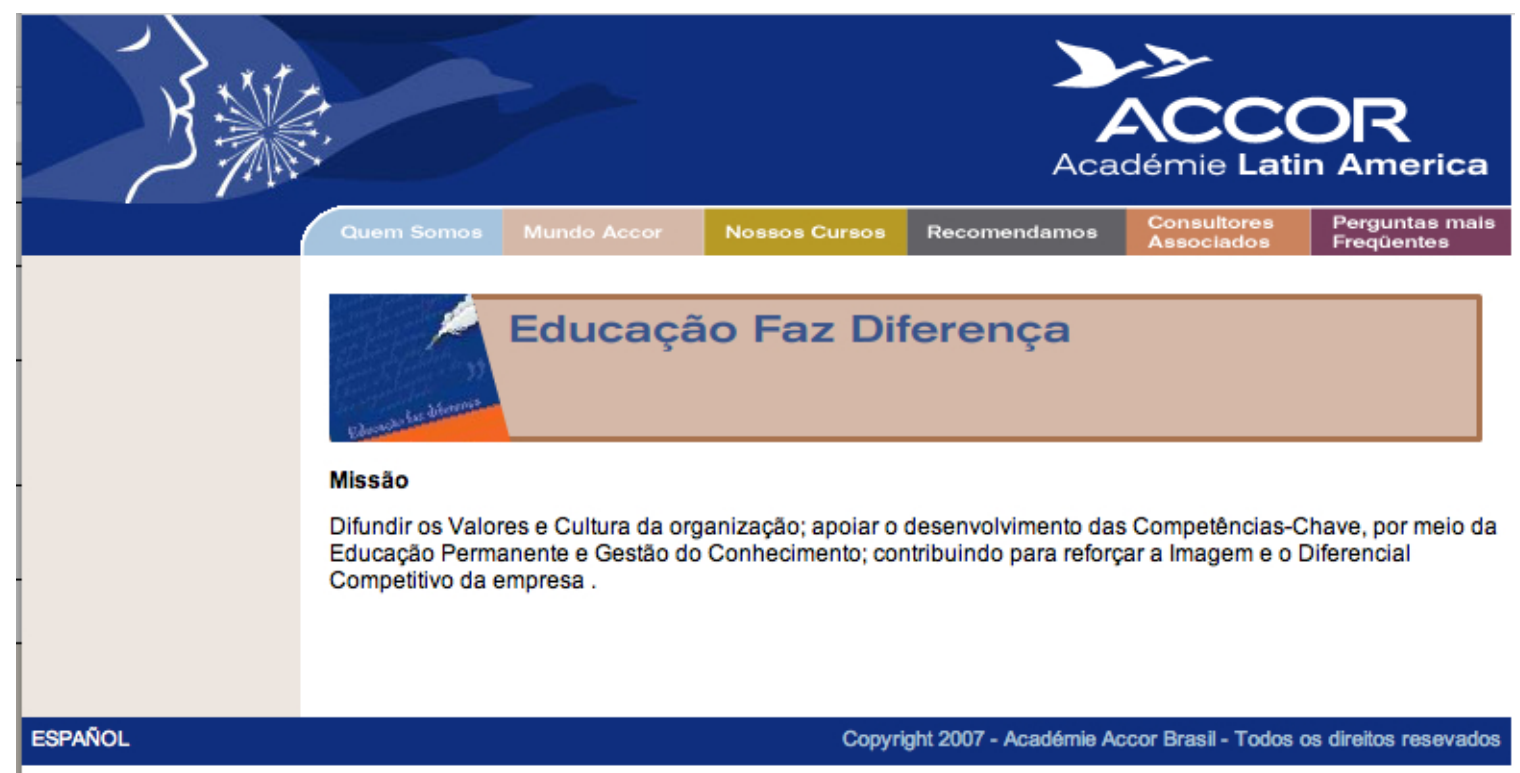

Embratel is Brazil's main telecommunication service provider. Embratel owns several subsidiaries: Brasilcenter, Star One, and Click 21, which combined employs approximately 12,000 people throughout Brazil. Embratel makes extensive use of its corporate intranet for corporate training and educational purposes. Embratel enjoys a long and established track record of investing in its employees. Indeed, before Embratel's intranet became operational, it was already using CD-ROMs and videos for corporate training purposes. The company's first elearning initiative took place in a partnership with the Pontifical Catholic University, and in 2004, Embratel deployed a new software platform for e-learning management. The intranet is coordinated by the Embratel Corporate University (UCE) and operates under the umbrella of Embratel's human resources department. Embratel's intranet content is clearly differentiated to serve its different corporate business units' unique educational needs. Each business unit can quickly access audiovisual training resources, online courses, and face-to-face training sessions. Saba Centra (Saba, 2008) software has also been used for virtual meetings and for other live instructional events such as conferences and workshops (Eboli, 2004). In most cases, learning and interaction is synchronous and typically supplemented with independent, self-paced study activities. 
Figure 5. Snapshot of the Santander (Brazil) main webpage

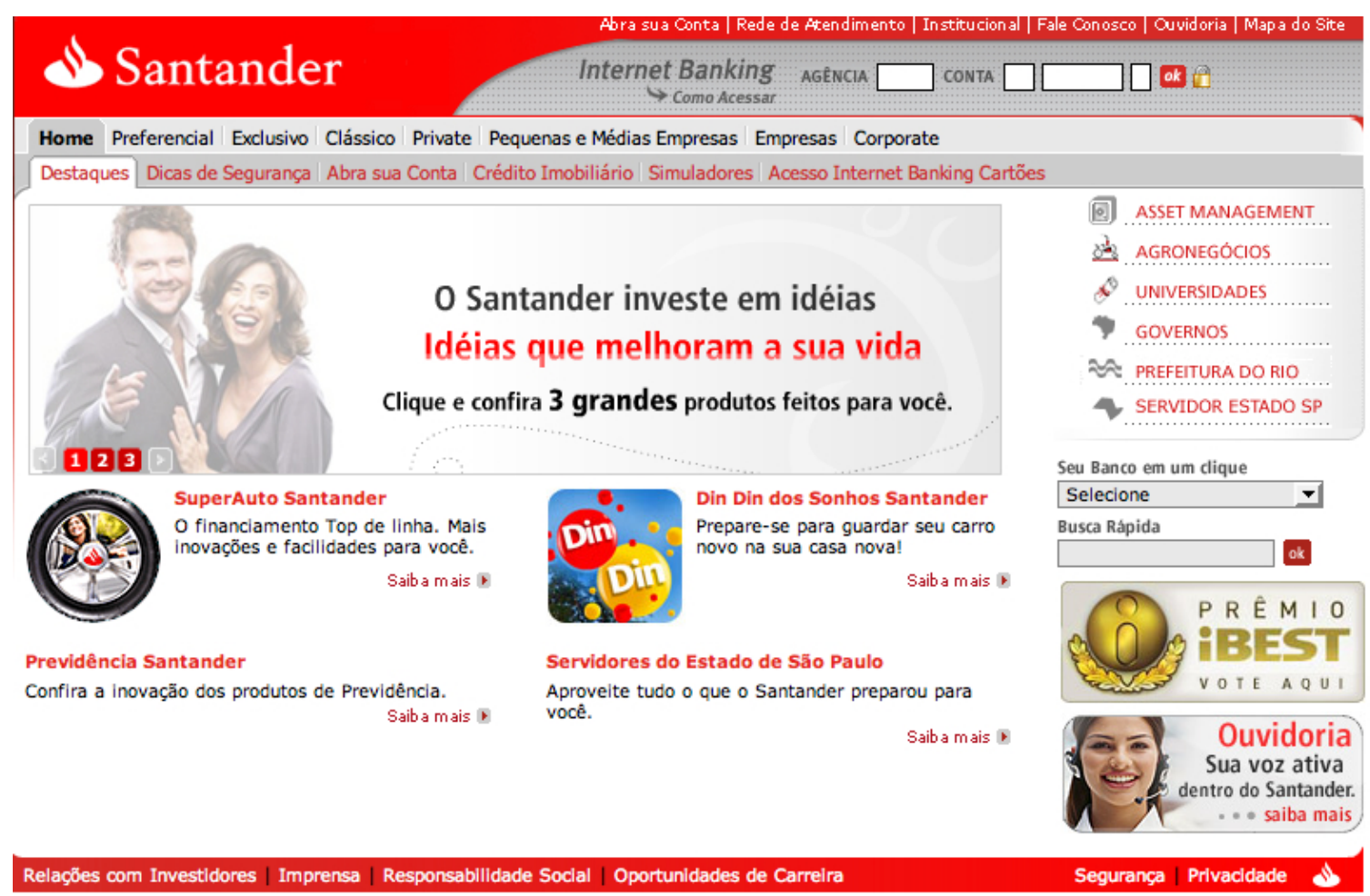

The Santander Group - banking and investment sector (Santander, 2008) - has for more than 10 years been developing the Santander Universities program, which in collaboration with IberoAmerican universities constitutes the axis of the corporate social responsibility of this organization. Today, there are more than 507 collaborative agreements that benefit approximately 9 million students and researchers, and almost 10 thousand scholarships are given. One important initiative of Santander Group in the educational arena is the Universia Portal (Universia, 2008). Universia was launched in Brazil in 2002, and since then it has established partnerships with more than 245 teaching institutions. This portal integrates and develops content and services according to the needs and requests from partnering institutions. It is used as a diffusion mechanism of news in the academic world about topics that include career, distance education, scholarships, scientific publications, and so forth. 
Figure 6. Snapshot of the Universia (Brazil) main webpage

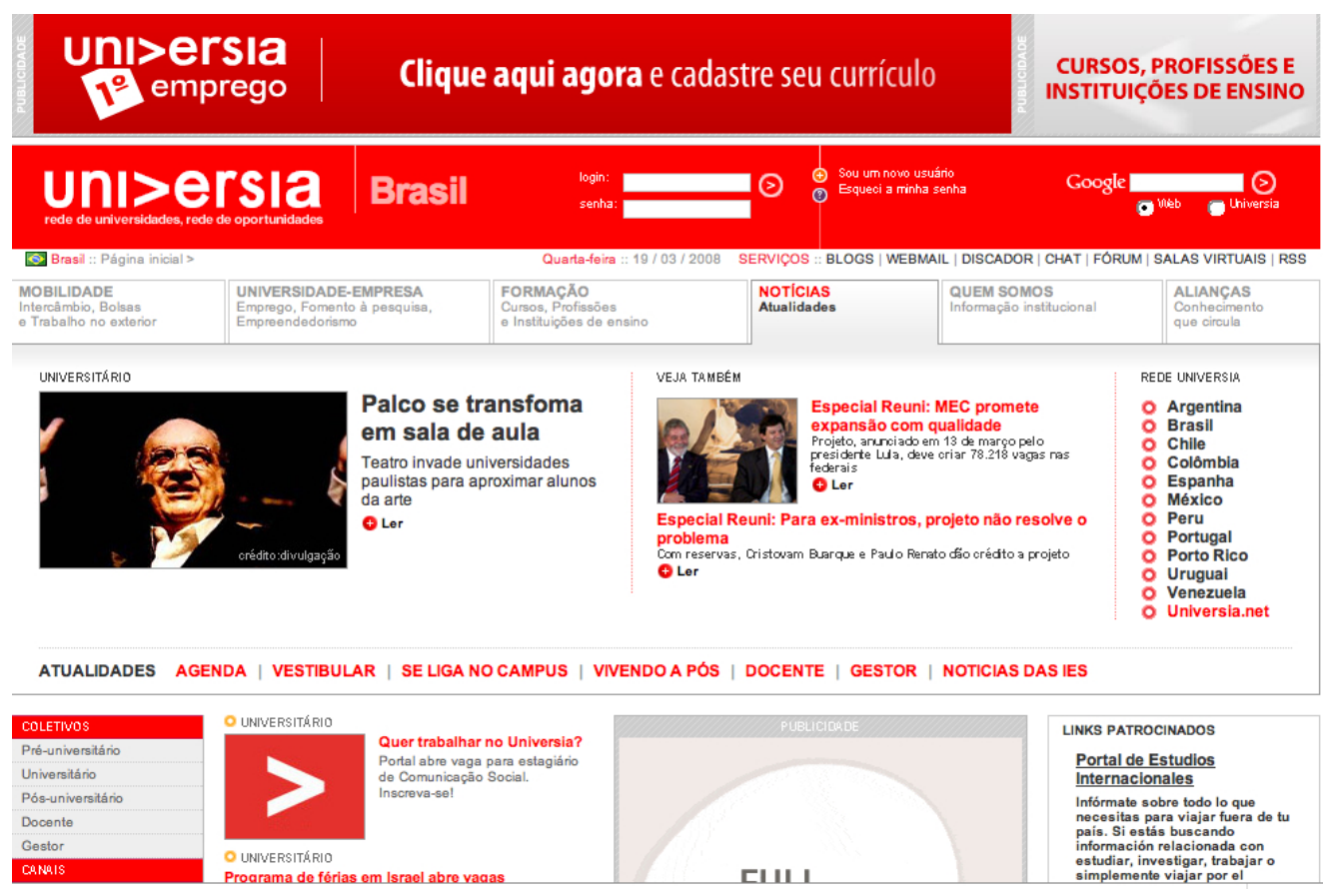

\section{Conclusions}

Old issues will undoubtedly influence and shape Brazil's future. The country must grapple with poverty, chronic employment, and issues surrounding increased and egalitarian access to education. Resolving these problems will help to reduce inequalities and consolidate and rally the Brazil's human resource capacity to compete more effectively in the global economy (Eboli, 2004). Corporate universities have been rising to this challenge - albeit mostly out of necessity to ensure their people have the right skills and knowledge they need to be competitive - and as such, the pace of distance education and e-learning has picked-up, primarily thanks to Brazil's corporate sector. These corporate universities have had helped to mobilize and prepare many Brazilians employed by these corporations (and for other corporations that contract with corporate universities). Nonetheless, most Brazilians, especially those hailing from poor families, rural regions, and impoverished socio-economic groups, have had little or no exposure to distance education or e-learning, let alone the opportunity to collaborate in any sort of online environment. Without basic exposure to e-learning, many Brazilians will simply not be able to participate and benefit from Brazil's growing economy.

The ongoing and chronic disconnect between the realities of what Brazil's public sector educational institutions can actually provide versus the nation's need for a highly skilled workforce, makes it extremely difficult to establish productive and meaningful collaborations between Brazil's private-sector corporations and its publicly-funded higher educational institutions. Brazil's Ministry of Education's long history of unreliable legislation and enforcing inflexible regulations, all of which is administered via its highly centralized bureaucracy, has jeopardized the legitimacy and lessened the impact of its publicly funded educational institutions. Oftentimes, Brazil's public universities are simply unable to use distance learning technologies (i.e., they are too highly regulated) and therefore lack the human capacity to use new and emerging e-learning technologies effectively. 
Ongoing and insufficient access to quality public education - much of which can be delivered online and at a distance - is hampering most Brazilians' ability to participate effectively, and benefit from, fruits of the global economy. With nearly 20 percent of Brazilian citizens still living below the poverty line, and many more working poor who simply lack resources to pay for education, illustrate that deep social inequalities are pervasive. And although many corporate universities have made inroads in meeting their own corporate educational needs, such corporate e-learning initiatives will likely also suffer. This is because Brazilians, although they have the infrastructure and have culturally embraced communication technologies, still suffer at the hands of inflexible legislators and view corruption as normal in Brazil. In this self-serving environment, corporate e-learning initiatives will be hard pressed to truly succeed. The good news is that the globalization of Brazil's economy - of which its corporations are at the vanguard of distance education - is fueling demand for change, and such growing demand will likely influence Brazil's culture. As discussed in Eboli (2004), recent studies show that corporate universities are viable, and the use of e-learning has played a significant role in expanding access to education albeit on a corporate level.

As these corporate-based employees use, gain proficiency, and benefit from workplace-centered e-learning, they will likely fuel demand for concomitant changes to occur across all of Brazil's higher education institutions. Demand for distance education to serve Brazilian citizens living far from metropolitan centers (where the universities are located) will likely increase. Higher education and continuing education, which is one of the drivers of online education, will be affected by current regulations that currently limit the amount of course work that can be done at a distance. Several enterprises are already playing an important role in this process through their focus on providing education and training to their workers, and no doubt others will follow.

\section{References}

Accor. (2008). Accor homepage. http://accor.com/gb/index.asp

Accor Academy (2008). Accord Academy in Brazil homepage. http://academie.accorbrasil.com.br/

AmBev. (2008). AmBev homepage. http://www.ambev.com.br/

Armengol, M. (2002). Global and critical visions of distance universities and programs in Latin America. International Review of Research in Open and Distance Learning, 3(2). http://www.irrodl.org/index.php/irrodl/article/viewFile/111/550

Bof, A. M. (2004). Distance learning for teacher training in Brazil. International Review of Research in Open and Distance Learning, 5(1). http://www.irrodl.org/index.php/irrodl/article/viewFile/172/684

Eboli, M. (2004). Educacao Corporativa no Brasil - Mitos e Verdades. [In Portuguese] Brasilia: Ed. Gente.

Embratel (2008). Embratel homepage. http://www.embratel.com.br/

Litto, F. M. (2001). Educacao inflexivel e tutelada. [In Portuguese] Jornal Correio Brasiliense. http://www.futuro.usp.br/producao_cientifica/artigos/fl_educacaoinflexivel.htm 
Litto, F. M. (2002a). Corporate virtual universities in Brazil - A glimpse of the scenario in 1999. Associação Brasileira de Educação a Distância website. http://www.abed.org.br/publique/cgi/cgilua.exe/sys/start.htm?infoid=176\&sid=104\&User ActiveTemplate $=4$ abed

Litto, F. M. (2002b). The hybridization of distance learning in Brazil - An approach imposed by culture. International Review of Research in Open and Distance Learning, 2(2). http://www.irrodl.org/index.php/irrodl/article/view/65/134

Litto, F. M. (2003). Perpectivas da educacao a distancia no Brasil: Tres cenarios a ponderar, 1997-2002 [In Portuguese]. Escola do Futuro da Universidade de São Paulo. Brazilian Review of Open and Distance Education. http://www.futuro.usp.br/producao_cientifica/artigos/fl_perspectivasead.htm

Litto, F. M. (2006). Public policy and distance learning in Brazil. White paper. Personal communication.

MEC (2005). Decree 5.622 published on December 20, 2005. [In Portuguese] Portal of the Distance Education Agency in the Ministry of Education of Brazil. http://portal.mec.gov.br/seed/arquivos/pdf/dec_5622.pdf

Ministério da Educação. (2007). E-tec Brasil. http://www.etecbrasil.mec.gov.br/index.php

National Geographic (2007). Brazil. http://www3.nationalgeographic.com/places/countries/country_brazil.html

Posseti, H. (2005). Empresas consolidam gestao com universidades corporativa. [In Portuguese] Portal do Voluntario. http://www.portaldovoluntario.org.br/site/pagina.php?idclipping=13680\&idmenu=62

Romiszowski, A. (2005). A study of distance education public policy and practice in the higher education sectors of selected countries: Synthesis of key findings. Background paper commissioned and published by the South African Council on Higher Education (CHE). http://www.che.ac.za/documents/d000070/Background_Paper1_Romiszowski.pdf

Saba (2008). Saba homepage. http://www.saba.com/products/centra/

SantanderBanespa. (2008). Santander Banespa homepage. http://www.santander.com.br/

Takahashi, F. (2006). Papel ainda domina o ensino a distancia. Folha de Sao Paulo. http://www1.folha.uol.com.br/folha/educacao/ult305u18541.shtml

The World Fact Book. (2007). Brazil. https://www.cia.gov/library/publications/the-worldfactbook/geos/br.html

Universidade Aberta do Brasil (2008). Universidade Aberta do Brasil homepage. http://uab.mec.gov.br/

Universia. (2008). Universia homepage. http://www.universia.com.br/ 
Wikipedia (2008, March 22). Educação a distância.

http://pt.wikipedia.org/wiki/Educa\%C3\%A7\%C3\%A3o_a_dist\%C3\%A2ncia\#Brasil

i The Gini coefficient is a measure of statistical dispersion most prominently used as a measure of inequality of income distribution or inequality of wealth distribution.

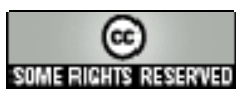

